\title{
Anatomy of the Nauplii of Oithona ovalis Herbst (Copepoda, Cyclopoida)
}

\author{
EDITH SUSANA FANTA \\ (Present adress: Dr. Edith S. Fanta Feofiloff - Dpto. de Zoologia, Universidade \\ de São Paulo. Caixa Postal 20.520, 01000 São Paulo, Brasil)
}

R E S U MO

Anatomia dos náuplios de Oithona ovalis Herbst (Copepoda, Cyclopoida)

Foram estudados 6 estágios naupliares do ciclopóide Oithona ovalis Herbst 1955 obtidos na natureza ou criados em laboratório.

Os náuplios vivos e as preparações histológicas foram observadas e descritas, a anatomia interna, o funcionamento de alguns órgãos e as mudanças que ocorreram durante o desenvolvimento naupliar. Atenção especial foi dispensada à musculatura e ao aparelho digestivo.

\section{A B S T R A C T}

All 6 naupliar stages of the Cyclopoid Oithona ovalis Herbst 1955, obtained from nature or reared in the laboratory, were studied.

The living nauplii and the histological preparations were observed, the internal anatomy, the functioning of some organs and the changes occurring during the naupliar development were described.

Special attention was given to the musculature and to the digestive system.

\section{N T RO D U C T I O N}

Oithona ovalis Herbst 1955, a cyclopoid of the family Oithonidae (see Björnberg 1972) is free-living and planktonic during all stages of its life. It is adapted to coastal and brackish waters (Björnberg, 1972; Teixeira et al., 1965; Tundisi, 1972). Due to the above mentioned special characteristics the nauplii adapt well to laboratory conditions and are easily reared.

Björnberg (1972) described the external morphology and some aspects of the behaviour of the 6 naupliar stages of $O$. ovalis. 
The external morphology of copepods in general is well studied because it is the main basis for all systematic studies. A lot of research has also been done about the biological behaviour and about the rearing of copepods and nauplii. But, as it was set-off by some authors (Gauld, 1959; Dudley, 1966; Walley, 1969; Fanta, 1972), a good understanding of the anatomical structures and functions of the adults, as well as the evolution of the groups, must take into account the structure and function of the organs in the naupliar stages.

Cyclopoid nauplii were studied by Claus (1858). Storch (1928) published a description of the swimming and feeding of Cyclops. The naupliar eye of Cyclopoids was described by Elofsson (1966). But the internal structure of the organs and the anatomical changes occurring during the development have not been investigated for Oithonidae.

Björnberg (1972) and Storch (1929) show the importance of locomotion and feeding during the naupliar life, therefore, more attention was given here to the description of the anatomy of the organs responsible for those functions.

Most of this work was done at the Zoology Department of the University of São Paulo. I am indebted to Dr. Tagea Björnberg for her valuable suggestions, and to the Fundação de Amparo à Pesquisa de São Paulo for finnancial support.

\section{MATERIAL AND METHODS}

The animals were collected throughout the year near the rocks in the bay of São Vicente, in the outlet of the Grande river in the Santos bay and at the Oceanographic Institute in Cananéia, State of São Paulo, on the Brazilian coast.

Collections were made near the surface, with plankton nets of $0,15 \mathrm{~mm}$ mesh apperture for adults and $0,06 \mathrm{~mm}$ for the naupliar stages of $O$. ovalis, most commonly stages III and IV

Observations in living animals, in total preparations and in histological sections were made for the descriptions.

All 249 nauplii observed were measured (Table I) and staged by morphological characteristics according to Björnberg $(1968,1972)$.

They were reared in $20 \mathrm{cc}$ of water (Murphy, 1923; Bernard, 1963; Fanta, 1972; Corkett \& Urry, 1968) in temperatures between 19 and $23^{\circ} \mathrm{C}$, the same as of the water where they were collected (Teixeira et al., 1965).

The technique used for rearing and observing the nauplii was the same described in Fanta (1972) for Euterpina acutifrons.

Some observations about the biology of the nauplii

The females of Oithona ovalis have 2 egg sacs with 5 to 10 eggs in each sac ( 8 in average). The eggs are spherical with a diameter of $5 \mu$. Near hatching time, the nauplii are ready and make some movements inside the egg membrane, and the contraction of the muscles of the legs can be observed (Fig. 2A). 
The eggs of Oithona ovalis are heavy and fall to the bottom of the aquarium if they are separated from the females, as in Euterpina acutifrons (Bernard, 1963; Fanta, 1972), Temora and Centropages, but not in Pontellidae and Paracalanidae with lipid containing eggs (Bernard, 1963, 1970). If the eggs fall to the bottom, which was rarely observed in natural conditions, they will not hatch, as in Notodelphyidae (Dudley, 1966), probably because of the action of microorganisms and lack of oxygenation.

The nauplius took 15 minutes for hatching. It rises its appendages to free itself from the envolving cap (Fig. 2B), and only one hour later swims normally. This has also been observed in Cyclops (Claus, 1858) and is different from Pseudodiaptomus acutus and Euterpina acutifrons (Fanta, 1972).

In all stages the swimming movements are characteristically spiral, with the help of the antennulae and the antennae. Long periods of floating with legs distended (Fig. 1) were also observed. In laboratory conditions, the nauplii of Oithona ovalis prefer to live near the surface and in suspension in mid-water, but not near the bottom. The larvae are transparent and have an oval body shape in all naupliar stages.

The nauplii hatched from the same egg sac, develop in different times. Eggs remain 48 to 72 hours in the egg sac before ecclosion. From the first to the last ecclosion of the same egg sac they need 20 hours. The development is fast and the time of development varies from the first nauplius to the first copepodite ( 72 to 96 hours). The nauplii are small and their size varies in all stages. The smallest nauplius measured $71 \mu$ (stage I) and the largest $200 \mu$ (stage VI). All measurements are on table 1 .

\section{RES U L T S}

\section{Internal anatomy}

To study the internal anatomy, living nauplii of all stages were observed, and then fixed and sectioned. Thus, it was possible to establish some correlations between the organs and their functions, mainly of the muscles and of the digestive system.

The transparency of a living animal during any one stage may vary. Animals recently molted and which have fasted are easier to observe.

Exoskeleton: The exoskeleton is composed of an inner cellular layer, the hypodermis or epidermis, and a protective covering, the cuticle. The cuticle is not homogeneous in thickness. At the anterior region of the nauplius, between the insertion of the antennulae, there is a thicker cuticle under which there is a space without cells, probably the "transitory crystaline" (Fig. 4B, 7D). In spite of the insertion of the strong leg muscles, the mid-dorsal region has no thickennings of the cuticle, not even at the stage VI.

The segmentation of the abdominal regions begins at stage IV and may be seen externally due to a fold of the cuticle. Internally the segments begin to develop ventrally being laterally completed only at the stage VI (Fig. 6A, B; 7A, B). 
Color of the nauplii: The color of the nauplii is caused mainly by 3 factors: the pigmentation of the cuticle, the color of the oil drops and the color of the intestinal contents. The light red pigment deposited in the naupliar eye is visible already in the egg (Fig. 2A). At the stage I the nauplii are transparent, with a small longitudinal dark green bar on the dorsal side, caused by a great amount of green globules, just below the epidermis. This is an easily observed characteristic, and helps with the identification of the species. At stages I and II the globules are present in a great quantity and the bar is divided in two at the anterior and the posterior ends (Fig. 2C, 3F).

From the stage III to the older stages, it becomes smaller and at the stage VI only 2 small groups of drops remain, one at the anterior and the other at the posterior region (Fig. 4I, 6A).

The cuticle in all stages is yellow colored in the furcal region (Fig. $3 \mathrm{~F}, 5 \mathrm{C}, 6 \mathrm{~A})$. The nauplii VI are red-pigmented laterally to each muscle, beginning at the insertion of the muscle on the dorsal side (Fig. 6A). Only in 3 out of 34 nauplii this was not observed.

Oil deposits: The oil is always more or less symmetrically arranged in drops and its color varies according to the food ingested by the animal. If it feeds on organic matter, the oil drops are light brown, but if the nauplii are fed with a pure culture of green algae, their color is light green. This coloring is caused by the big oil drops observable in all stages (Fig. 2C, 3F, 4A, 5E, 6A). In stage I there are also small red drops medio-lateral in position and one oil drop on either side of the posterior midgut (Fig. 2D). The amount and the size of the drops varies from animal to animal, but their position is always the same. At stage II and in the following stages, there is an oil storing tissue containing green oil over the intestine, centrally, extending from the anterior to the posterior region, and branching posteriorly (Fig. 3C, 4H, 6A).

Musculature: All the appendicular muscles have striations that may be observed either in living or in fixed animals, even before the hatching of the nauplius. The nauplii do not have the longitudinal muscles which in the adult stage move the body and its segments, but only the transverse muscles which extend from the body wall into the appendages.

The antennulae, antennae and mandibles are used for locomotion. The maxillules occurring in advanced stages are rudimentary and are not used as locomotory organs.

From the earliest stage, the muscles of each appendage are parallel, arranged in a V-like angle with the tip of the $\mathrm{V}$ turned posteriad in dorsal view (Fig. 3B). The muscles are inserted at the dorsal median line and gradually, as the animal grows older, the insertion becomes more lateral for the posterior muscles (Fig. 7E). The anterior muscles are situated more to the surface and the posterior ones more to the interior of the nauplius (Fig. 7E, 8C). The muscles enter the appendages inserting laterally in the opposite sides of the basal segments (Fig. 5E). Some smaller muscles penetrate until the third segment. If the upper muscles contract, the antenullae are pulled forewards, and the contraction of the opposite muscle results in an opposite movement. 
From the earliest stage, each appendage receives at least 2 muscles, allowing simple rowing or paddle-like movements. In later stages the number of muscles for each appendage increases and the nauplius may execute more complex movements. The movements of the antennulae, antennae and mandibles also cause a water current directed towards the mouth. The antenna has a branch with hooks at its base, which moves forwards and backwards, helping to lead the food particles to the mouth.

The muscles do not divide before inserting dorsally. Even the thick muscles of nauplius VI insert as a whole (Fig. 7E).

Inside the egg, one may observe 6 muscles (Fig. 2A), which have short contractions. At the beginning of the ecclosion, these muscles contract repeatedly moving the appendages, and this helps the nauplius to become free of the enveloping cap. The swimming function will only be assumed by the muscles after a resting period. The nauplius then swims and searches for food.

Nauplii I and II have 6 pairs of appendage muscles: 2 are mandibular, 2 antennal and 2 serve the antennullae (Fig. 3B, 3E). At stage III the nauplii have 8 pairs of these muscles: 2 are mandibular, 3 antennular and 3 antennal. The third muscle of the antenna lies obliquely to the others, and the appendages which have 3 muscles can execute differentiated movements (Fig. 4D).

At stage IV 13 pairs of muscles can be seen: 3 pairs to the antennules, 3 to the antennae, 3 to the mandibles, and 2 short muscles to the maxillulles, which are perpendicular to all the others (Fig. 5A).

The nauplii $\mathrm{V}$ and VI have 12 pairs of muscles; 3 to the antennules, 4 to the antennae, 3 to the mandibles and 2 to the maxillules (Fig. $7 \mathrm{C}$ ).

The wall of the oesophagus, the midgut and the posterior midgut have muscles, apparently non-striated (Fig. 8, 9).

The digestive tract: The egg of $O$. ovalis contains no yolk and from the earliest naupliar stage, the intestine is open and functional, consisting of the mouth, the oesophagus, the midgut, the hindgut and the anus.

The mouth is a ventral split, which moves quickly for some short periods, remaining closed for the most part of the time (Fig. 2D, 5D).

The oesophagus curves forwards for a short distance dorsad, then backwards into the midgut more ventrally (Fig. 3G).

The midgut is the largest part of the digestive tube, with glandular and mucous cells which penetrate the supporting tissue on the boundary region (Fig. 8, 9). Posteriorly the midgut is mainly muscular (Fig. 6C).

The undigested food may remain in the anterior as well as in the posterior region of the midgut. In the anterior midgut it is moved forwards and backwards, and mixed with mucus secreted by the mucous cells of the midgut (Fig. 8, 9). In the posterior region the food rests become spherical and remain aggregated.

The alimentary tube ends in a short hindgut which opens out through the anus from the first naupliar stage. The anus is a dorsal split between the furcal setae (Fig. 5G).

The posterior intestine has very reduced chitinous walls and dilates for the expulsion of the feces. It also moves rythmically perhaps for respiration. 
In the nauplius I individual cells cannot be distinguished in the anterior midgut (Fig. 2D). There is a very delicate musculature in the walls of the gut and contraction waves may be seen from the posterior to the anterior region. There is a slight constriction separating the anterior and the posterior midgut. Anterior to this constriction there is an enlargement of the intestinal walls forming a specific place for the deposit of urinary concretions. The posterior midgut is spherical with thick muscular walls which contract strongly, reducing its diameter to one half of the usual size (Fig. $3 \mathrm{H}, \mathrm{I}$ ).

In stage II the naupliar body is longer as well as the digestive tube. The anterior cellular and the muscular posterior midgut can be seen more clearly. The deposit of concretions is also longer and its contents spread towards the median region. Anterior to this region, the intestine wall may contract strongly. In the anterior midgut the beginning of a dorsal subdivision can be observed.

Nauplius III (Fig. 4F) has the cells of the anterior midgut perfectly visible, also in the living animal. The number of concretions increases. The posterior midgut is differenciated into 2 regions: one, a cellular and muscular region, and the other with a thick musculature. There are muscle fibres joining the intestine wall to the body wall, and their contractions push and pull the intestine wall (Fig. 4E). Nauplius IV (Fig. 5B) has a sphincter between the anterior and the posterior midgut.

In nauplii $\mathrm{V}$ (Fig. $5 \mathrm{FG}$ ) and VI (Fig. $6 \mathrm{C}, \mathrm{D}$ ) there are 3 regions in the anterior midgut: one, anterior with visible cells, separated from the second without visible cells, by a dorsal fold; and the concretion sac.

Excretion: Inside the intestinal walls of the midgut, anterior to the sphincter, there is a deposit of green granules in a latero-ventral position. These are urinary concretions which are neither liberated to the exterior through the intestine, nor directly through the ducts.

In the nauplii I and II these are 4 spherical grains on each side (Fig. 3A, I) which increase in number during the naupliar development. At stage I and II they rearranged in a row and at stage III they become more numerous, irregularly arranged (Fig. 4G, 5G, 6C).

At the beginning of stage III they are deposited in 2 sacs, one on each side of the intestine, and, thus, they can be observed throughout the rest of the naupliar development.

Respiration and circulation: The nauplii of $O$. ovalis do not have specific areas for respiration excepting for the anal region where rhythmic movements can be observed for short periods. At the first stages of development they can be seen easily. There is also no defined circulatory system, and the body fluids are transparent, without corpuscles.

Glands: They were observed in living animals and in histological preparations, but no histochemical studies for their identification were made.

Nauplius I has two glands in the posterior region of the body, containing green granules, and opening laterally in a cuticle fold (Fig. 2C). Nauplius II also has two labral glands with a visible opening to the 
exterior and with the contents not colored (Fig. 3D). At stage III two glands with ventral opening at the posterior region of the body (Fig. 4E) can be observed. At nauplius IV there is one more pair of glands in the labrum. Behind the naupliar eye, the two protocerebral glands (Fig. $4 \mathrm{~J}, \mathrm{H}$ ) can be seen. Nauplius $\mathrm{V}$ has 3 pairs of labral glands with orange content (Fig. 5D). Nauplius VI has two glands laterally with orange content near to the anterior margin of the first abdominal segment (Fig. $6 \mathrm{~B}, \mathrm{D})$.

\section{Nervous system and naupliar eye}

A specific staining for the nervous system was not made; only the structures visible in living animals or in histological preparations stained with Mallory's triple stain were described.

The naupliar eye with its light red pigment is visible from the egg stage (Fig. 2A). It is small, divided into 2 spherical parts, the ventral and the two dorsal cups (Fig. 4B). The red pigment concentrates in the median region where the cups touch, and the ventral cup does not contain pigment (Fig. 4B). The eye is located anteriorly near the cuticle and ventrally there is a space probably occupied by body fluids, the transitory crystaline (Fig. 4B, 7D).

The brain is dorsally located, a little behind and below the naupliar eye. The protocerebrum is visible in the living animal from the nauplius I, and divides into two nervous lobes with a median fissure beginning at stage IV (Fig. 3C, 4B, 7D).

From the anterior part of the cerebrum 3 optic nerves extend to the naupliar eye: 2 dorsal and 1 ventral. Laterally two nerves extend to the basis of the antennulae, possibly to the $X$ organ (Fig. 4B).

\section{DISCUSSION AND CONCLUSIONS}

Cuticle: The resting period of the nauplii of Oithona ovalis, soon after ecclosion may be due to the fact that the cuticle is still insufficiently firm to support and to offer resistance to the muscles during the strong swimming movements. The same was observed by Claus (1858) in Cyclops, but it does not occur in Euterpina acutifrons (Fanta, 1972) nor in Pseudodiaptomus acutus (Fanta, in press) and in other species (Björnberg, 1972).

The nauplii of $O$. ovalis do not have a thickenning of the chitin in the dorsal region where the muscles are inserted, contrary to what is observed in the nauplii of Cyclops (Claus, 1858) and in the adults of Calanus finmarchicus (Lowe, 1935).

The thickennigs which occur in the labrum of $O$. ovalis are also found in Cyclops (Claus 1858) where they form crenated chitinized teeth. Their function is perhaps to protect important regions such as the mouth and the inferior part of the brain, as they are not related to muscle insertion.

The delicate anterior thickennigs of the naupliar eye, present in the naupliar stages of $O$. ovalis, may be very developed in certain copepod groups forming the corneal lenses ("corneallinsen") discussed by Claus (1858) and Gicklhorn (1930) for Cyclops. Even when well developped, 
the authors do not agree about whether these structures are or not optically functional.

In $O$. ovalis the first segmentation of the body begins in nauplius IV and is completed in nauplius VI, the same as in Pseudodiaptomus acutus (Fanta, in press). Thus, it occurs later than in the harpacticoid Euterpina acutifrons (Fanta, 1972) where it is already observed in stage 3 , and sooner than in Calanus (Grobben, 1881; Marshall and Orr, 1955) and in Cyclops (Claus, 1858) where the segmentation is rudimentary, composed of connective tissue fibers which extend from the intersegmentary areas to the intestine only in the naupliar stage VI.

Pigmentation: When compared to the nauplii of some pelagic copepods and to the Notodelphyid nauplii (Canu, 1892), those of $O$. ovalis are transparent and not colored. The colors of the cuticle are only observable under strong magnification.

The colors are due to the gut contents and to deposits of fat which can be seen by transparency just as in other Cyclopoida such as Cyclops tenuicornis and C. serrulatus (Claus, 1858).

Oil deposits: the size of the oil droplets in $O$. ovalis is small, contrary to what occurs in other copepods: Pseudodiaptomus acutus (Fanta, in press), Euterpina acutifrons (Fanta, 1972), and Diaptomus (Gurney, 1931).

Oithona ovalis has a special fat storing tissue, similar to the one observed by Gnanamuthu (1948) in the adult Caligus savala. This tissue lheps the $O$. ovalis nauplius to fluctuate near the surface, where it moves very little.

Musculature and movements: the striated muscles which can already be seen in the egg of $O$. ovalis are characteristic of the Arthropoda (Andrew, 1959) and the muscular movement of planktonic crustaceans is necessary to renew the water continuously over the surface of the body, favouring the taking of food and respiration (Wolvekamp and Waterman, 1960).

In $O$. ovalis the muscles do not divide for insertion as in other Cyclopoida (Gurney, 1931), but they also differ in this aspect from the Pseudodiaptomus acutus (Fanta, in press).

The appendage musculature enables the $O$. ovalis nauplius to make rowing movements as in Cyclops (Claus, 1858; Storch, 1929; Gauld, 1959). There seems to be a difference between the appendages used for locomotion in the adult Cyclopoida. In these the movement is only due to the legs, and the antennule moves backwards and forwards because of internal hydraulic pressure.

The parallel disposition of the muscles, reducing the variety of movements, is comparable to the simple musculature of the Notodelphyids (Dudley, 1966; Canu, 1892) and of the calanoid Eurytemora velox, and contrary to the other calanoids where it is very complex (Gurney, 1932). These simple movements are appropriate for the purely planktonic life of $O$. ovalis, which, when swimming makes simple rowing movements or 
"paddle movements" (Björnberg, 1972). Figure 10 summarizes the development of the appendage muscles in $O$. ovalis nauplii.

Digestive system: the general aspect of the digestive tube, observable in $O$. ovalis nauplii, from nauplius $\mathrm{I}$, is common to all crustaceans, including adult copepods and their nauplii (Vonk, 1960); the foregut or stomodaeum, the hindgut or proctodaeum, both of ectodermic origin, and, the midgut or mesenteron, of endodermic origin (Andrew, 1959).

The ventral mouth is characteristic of the class and has been described for other adults and nauplii.

The oesophageal chitin is very thin and vestigial, differing from the adult Cyclopoida (Claus, 1858; Leydig, 1859; Zenker, 1854) and from the Notodelphyid nauplii (Dudley, 1966). No muscle fibers were found in these as they occur in the oesophagus of $O$. ovalis and also of Pseudodiaptomus acutus (Fanta, in press).

The adult Cyclops has a diverticulum in the midgut (Farkas, 1923) which was not found in the nauplii of $O$. ovalis.

The intestine of $O$. ovalis is very simple comparatively. The sphincter which $O$. ovalis has between the anterior and the posterior portion of the midgut was observed in other nauplii such as Pseudodiaptomus acutus (Fanta, in press), Euterpina acutifrons (Fanta, 1972) and in adults and nauplii of Cyclopoida (Claus, 1858; Farkas, 1923; Leydig, 1859).

In the Notodelphyid nauplii (Dudley, 1966) and in the Calanus finmarchicus nauplii (Grobben, 1881; Marshall \& Orr, 1955) the intestine is open only in more advanced stages, whereas in $O$. ovalis, as well as in Pseudodiaptomus acutus (Fanta, in press) and in Euterpina acutifrons (Fanta, 1972), it is open from the first naupliar stage. In nauplii VI the intestine of $O$. ovalis has the same basical aspect as in that of the adult Cyclops (Farkas, 1923).

The peristaltic and antiperistaltic movements which occur in the intestine of the $O$. ovalis nauplii, are important for the pushing forward of the food. The digestion seems to occur in the anterior part of the midgut and the absortion takes place more posteriorly (Vonk, 1960). The posterior midgut is for the formation of the fecal pellet. The muscle fibers which move the intestinal walls, form a thin layer in the gut as in adult Cyclops (Claus, 1858). There are also the outer muscles which originate in the body wall and insert in the wall of the digestive tract. These can be seen in the adult Cyclops (Farkas, 1923) and from nauplius III in $O$. ovalis. An increase in the diameter of the digestive tube causing the circulation of its contents is brought about by the movements of these muscles. They were not found in the harpacticoid Euterpina acutifrons (Fanta, 1972).

The feces are mixed with mucus and enveloped by a thin peritrophic membrane (Andrew, 1959; Vonk, 1960) visible only in histological sections of $O$. ovalis. In this species there occur at the same time fecal pellets in the hindgut and the elimination of feces while food is being digested in the midgut. This shows that the animal feeds more frequently and at smaller intervals of time than necessary for the complete digestion of the food. The taking of food is not continuous, because the mouth moves only periodically. 
The changes in the digestive system occurring during naupliar development are represented in Figure 11.

Excretion: the two sacs of inclusions present in the midgut of $O$. ovalis also occur in Cyclops (Claus, 1858), and seem to contain urin concretions. In Cyclops the grains are expelled and formed again whereas, in $O$. ovalis they are not liberated through the 5 naupliar stages. In both, the concretions become more numerous, and gradually of smaller diameter at each successive naupliar stage. The same was described for adult cyclopoids (Farkas, 1923; Leydig, 1859).

$O$. ovalis has a gland which seems to be the maxillary gland, by analogy to the excretory organ with yellow contents described in Cyclops (Zenker, 1854).

Respiration: the nauplii of $O$. ovalis have no especial region or structure for the exchange of gases. This happens through the thin and extensive body surface as in the other free-living copepods and in all crustacean larvae (Wolvekamp and Waterman, 1960).

The movements of opening and closure of the hindgut and of the anus during some periods were observed in small crustaceans, both young and adults, and may have a respiratory function (Wolvekamp and Waterman, 1960). But, Fox (1952) concludes that this pumping motion is used to establish intestinal peristaltism and antiperistaltism, mostly during the first stages; later on the intestinal movements will become independent from the anal. The anal respiration observed in nauplii is probably not indispensable as it is sporadic.

Circulation: Contrary to the nauplii of Euterpina acutifrons (Fanta, 1972), those of $O$. ovalis have no pulsating dorsal vessel. Cyclopoids and Harpacticoids have no heart but the adults have a central organ in the thorax. The fluids circulate probably due to the movements of the intestine (Claus, 1858; Leydig, 1859; Zenker, 1854), the muscles, the appendages and the body.

Glands: the labral glands occur in O. ovalis, in Pseudodiaptomus acutus (Fanta, in press) in the Notodelphyids (Dudley, 1966), in the adult Cyclops (Farkas, 1923) and in Euterpina acutifrons (Fanta, 1972) and seem to be very common in the copepods. Lowe (1935) describes labral glands as multinucleate cells which are situated along the length of the labrum, but, in O. ovalis, as well as in Diaptomus, Cyclops, Calanus and Pseudodiaptomus they are composed of simple cells (Leydig, 1859; Richard, 1891; Fanta, in press).

Nervous system: the protocerebrum is dorsal and immediately posterior to the naupliar eye, as in Notodelphyideae (Dudley, 1966), and contrary to what Hanström (1924) says to occur in all copepods. The protocerebrum is separated from the dorsal epidermis.

The naupliar eye: the eye of $O$. ovalis differs from the Cyclops eye (Elofsson, 1966) because it is situated near to the dorsal epidermis. In Cyclops it is near to the frontal epidermis between the dorsal and the 
ventral sides. The muscles related to the naupliar eye of adult Cyclopoida (Leydig, 1859) were not observed in $O$. ovalis.

The corneal lenses, well developped in the adult Cyclopoida and in several other groups (Claus, 1858; Gicklhorn, 1930), are very thin in $O$. ovalis. The space situated just below is considered as the transitory crystalline (Richard, 1891) but it was impossible to see the nerves which Gicklhorn (1930) described and it is doubtful that the "crystalline" may help in the vision.

General conclusions about the time of development of the naupliar structures of $O$. ovalis can be seen in Figure 12 .

\section{LITERATURE CITED}

ANDREW, W. - 1959 - Text book of comparative Histology. Oxford Press, New York, $652 \mathrm{pp}$.

BERNARD, M. - 1963 - Le cycle vital en laboratoire d'un copépode pélagique de Méditerranée Euterpina acutifrons Claus. Pelagos, 2: 35-48.

BERNARD, M. - 1970 - Quelques aspects de la biologie du copépode pélagique Temora stylifera en Méditerranée. Pelagos, 11: 1-196.

BJORNBERG, T. K. S. - 1968 - Estágios de desenvolvimento de alguns copépodos marinhos planctônicos tropicais e subtropicais. Tese apres. conc. de Doc. livre na cad. de Zoologia da Fac. Fil. Cienc. Letr. da U.S.P.

BJORNBERG, T. K. S. - 1972 - Developmental stages of some tropical and subtropical planktonic marine copepods. Stud. Fauna Curaçao Caribbean Is., 40(136): 185 pp.

CANU, E. - 1892 - Les copépodes du Boulonnais - morphologie, embryologie, taxonomie. Trav. Stat. Zool. Wimmereux., 6: 1-354.

CLAUS, C. - 1858 - Zur Anatomie und Entwickelungsgeschichte der Copepoden. Arch. Naturgesch. Jahrg., 24, 1/2: 1-76.

CORKETT, C. V. \& D. L. URRY - 1968 - Observations on the keeping of adult female Pseudocalanus elongatus under laboratory conditions. J. Mar. biol. Ass. U.K., 48: 97-105.

DUDLEY, P. - 1966 - Development and systematics of some Pacific Marine Symbiotic Copepods (Notodelphyidae). Univ. of Wash. Press. Seattle. $282 \mathrm{pp}$.

ELOFSSON, R. - 1966 - The nauplius eye and frontal organs of the non-malacostraca (Crustacea). Sarsia, 25: 1-128.

FANTA, E. S. - 1972 - The anatomy of the nauplii of Euterpina acutifrons (Copepoda, Harpacticoida). Crustaceana, 23(2): 165-181.

FANTA, E. S. - The anatomy of the nauplii of Pseudodiaptomus acutus (Copepoda, Calanoida). (in press).

FARKAS, B. - 1923 - Beiträge zur Kenntniss der Anatomie und Histologie des Darmkanals der Copepoden. Acta Litt. Scient. Reg. Univ. Francisco Josephinae. Sect. Scient. Nat., 1: 47-76. 
FOX, H. M. - 1952 - Anal and oral intake of water by Crustacea. J. Exp. Biol., 29: 583-599.

GAULD, D. T. - 1959 - Swimming and feeding in Crustacean larvae: the nauplius larva. Proc. Zool. Soc. Lond., 132: 31-50.

GICKLHORN, J. - 1930 - Notiz über die sogenannten "Cornealinsen" von Cyclops strenuus Fischer. Zool. Anz. 90: 250-258.

GNANAMUTHU, C. P. - 1948 - Notes on the anatomy and physiology of Caligus savala n. sp. a parasitic copepod from Madras plankton. Proc. Zool. Soc. Lond., 118: 591-606.

GROBBEN, C. - 1881 - Die Entwicklungsgeschichte von Cetochilus septentrionalis Goodsir. Arb. Zool. Inst. Univ. Wien., 3: 1-40.

GURNEY, R. - 1931 - British fresh-water Copepoda. Ray Society, London, 1: 236 pp.

GURNEY, R. - 1932 - British fresh-water Copepoda. Ray Society, London, 2: 336 pp.

HANSTRÖM, B. - 1924 - Beitrag zur Kenntnis des zentralen Nervensystems der Ostracoden und Copepoden. Zool. Anz., 61: 31-38.

HEBERER, G. - 1927 - Beiträge zur Biologie der freilebenden Copepoden der Umgebung von Halle A. S. Zeitschr. f. Naturwiss., 87: 105-186.

LEYDIG, F. - 1859 - Bemerkungen über den Bau der Cyclopiden. Arch. Naturg., 25: 195-206.

LOWE, E. - 1935 - The anatomy of a marine copepod Calanus finmarchicus (Gunnerus). Trans. roy. Soc. Edinb., 58: 561-603.

MARSHALL, S. M. \& A. P. ORR - 1955 - The biology of a marine Copepod. Edinburgh. Oliver \& Boyd. 188 pp.

MURPHY, H. E. - 1923 - The life cycle of Oithona nana, reared experimentaly. Univ. Calif. Publ. Zool. Berkeley, 22: 449-454.

RICHARD, J. - 1891 - Recherches sur le système glandulaire et sur le système nerveux des copépodes libres d'eau douce. Ann. Sci. Nat. Paris, ser. 7, Zool., 12: 113-270.

STORCH, O. - 1928 - Der Nahrungserwerb zweier Copepoden-Nauplien, Diaptomus gracilis, und Cyclops strenuus. Zool. Jb. Zool. Physiol., 45: 385-436.

STORCH, O. - 1929 - Die Schwimmbewegung der Copepoden auf Grund von Mikrozeitlupenaufnahmen analysiert. Verh. Dtsch. Zool. Ges., 33: 118-129.

TEIXEIRA, C.; J. TUNDISI \& M. B. KUTNER - 1965 - Plankton studies in a mangrove environment. II. The standing-stock and some ecological factors. Bol. Inst. oceanogr. São Paulo, 15: 13-42.

TUNDISI, T. M. - 1972 - Aspectos ecológicos do zooplâncton da região lagunar de Cananéia com especial referência aos Copepoda (Crustacea). Tese apres. ao Dep. de Zoologia do Inst. de Bioc. da U.S.P. para obt. título de Doutor em Ciências. 190 pp.

VONK, H. J. - 1960 - Digestion and Metabolism. In: Waterman, T. H. (ed.). The Physiology of Crustacea. Acad. Press. New York, 1: 291-316.

WALLEY, L. J. - 1969 - Studies on the larval structure and metamorphosis of Balanus balanoides (L.). Phil. Trans. Roy. Soc. Lond. B. bull. Sc., 256(807): 237-280. 
WOLVEKAMP, H. P. \& T. H. WATERMAN - 1960 - Respiration. In: T. H. Waterman (ed.). The physiology of Crustacea. Acad. Press New York, 1: 35-100.

ZENKER, W. - 1854 - Ueber die Cyclopiden des süssen Wassers. Arch. f. Naturg., 20: 88-102.
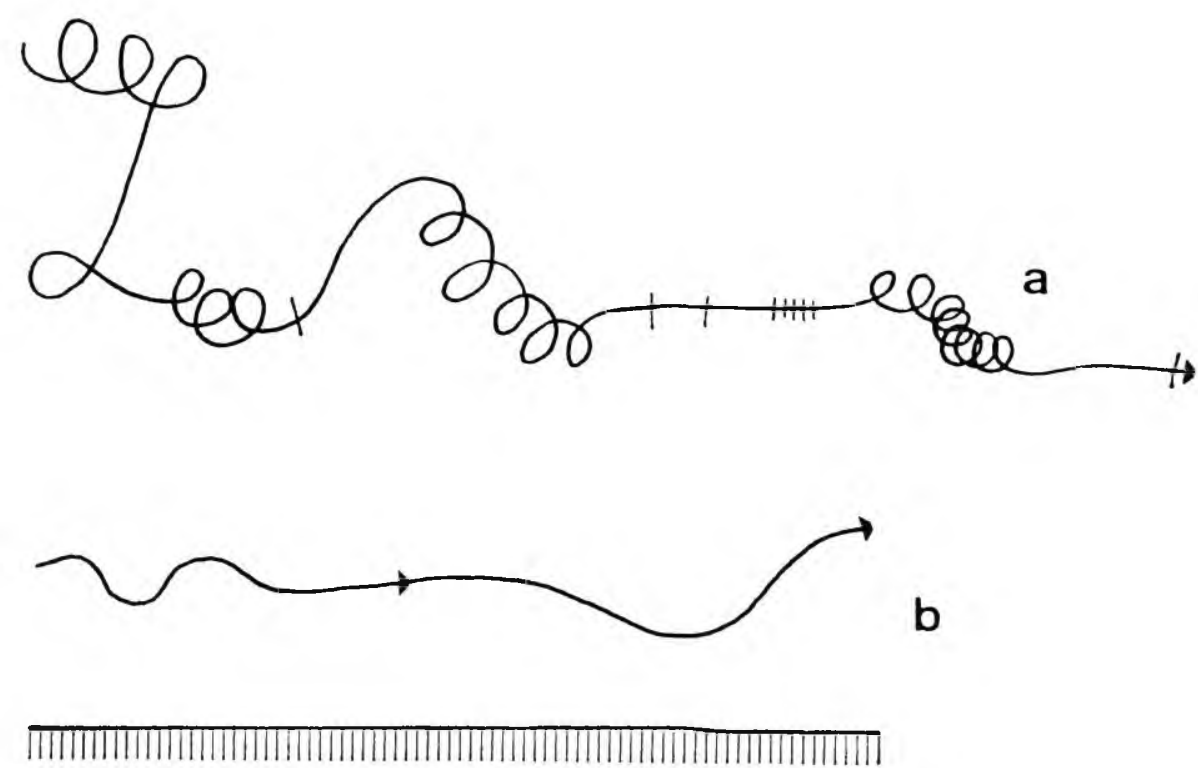

Fig. 1 - Diagram of the direction (simple line) of the movements of the nauplii of $O$. ovalis: a - the movement seen from above (the intervals between two bars are equal to 5 seconds); $b$ - the movement of the nauplius relatively to the bottom (seen in profile). 


\begin{tabular}{|c|c|c|c|c|c|c|}
\hline 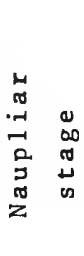 & 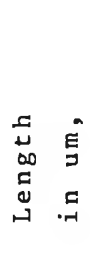 & 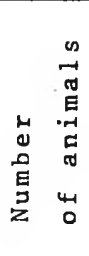 & 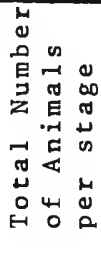 & $\begin{array}{l}E \\
g \\
.5 \\
.+1 \\
0 \\
0 \\
0 \\
\Sigma\end{array}$ & 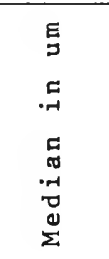 & $\begin{array}{l}0 \\
\infty \\
\pi \\
0 \\
0 \\
0 \\
0 \\
0 \\
0\end{array}$ \\
\hline 1 & $\begin{array}{r}71 \\
85 \\
90 \\
92 \\
100 \\
103\end{array}$ & $\begin{array}{r}3 \\
18 \\
6 \\
6 \\
3 \\
3\end{array}$ & 39 & 85 & 88,3 & $\begin{array}{r}7,7 \\
46,1 \\
15,4 \\
15,4 \\
7,7 \\
7,7\end{array}$ \\
\hline 2 & $\begin{array}{l}100 \\
103 \\
105 \\
107 \\
110 \\
114\end{array}$ & $\begin{array}{r}7 \\
1 \\
11 \\
2 \\
2 \\
16\end{array}$ & 39 & 114 & 107,6 & $\begin{array}{r}17,9 \\
2,7 \\
28,2 \\
5,1 \\
5,1 \\
41,0\end{array}$ \\
\hline 3 & $\begin{array}{l}107 \\
114 \\
121 \\
125 \\
128 \\
142\end{array}$ & $\begin{array}{r}3 \\
10 \\
8 \\
1 \\
16 \\
5\end{array}$ & 43 & 128 & 123,5 & $\begin{array}{r}7,0 \\
23,2 \\
18,6 \\
2,4 \\
37,2 \\
11,6\end{array}$ \\
\hline 4 & $\begin{array}{l}125 \\
135 \\
142 \\
145 \\
149\end{array}$ & $\begin{array}{r}18 \\
31 \\
2 \\
10 \\
3\end{array}$ & 64 & 136 & 134,6 & $\begin{array}{r}28,1 \\
48,4 \\
3,1 \\
15,7 \\
4,7\end{array}$ \\
\hline 5 & $\begin{array}{l}142 \\
145 \\
185\end{array}$ & $\begin{array}{r}5 \\
17 \\
8\end{array}$ & 30 & 145 & 155,1 & $\begin{array}{l}16,7 \\
56,6 \\
26,7\end{array}$ \\
\hline 6 & $\begin{array}{l}165 \\
171 \\
192 \\
200\end{array}$ & $\begin{array}{r}8 \\
20 \\
5 \\
1\end{array}$ & 35 & 171 & 173,5 & $\begin{array}{r}23,6 \\
58,8 \\
14,7 \\
2,9\end{array}$ \\
\hline
\end{tabular}

TABLE 1 - Number of nauplii examined, their length and percentage of occurrence of lengths in each stage. 


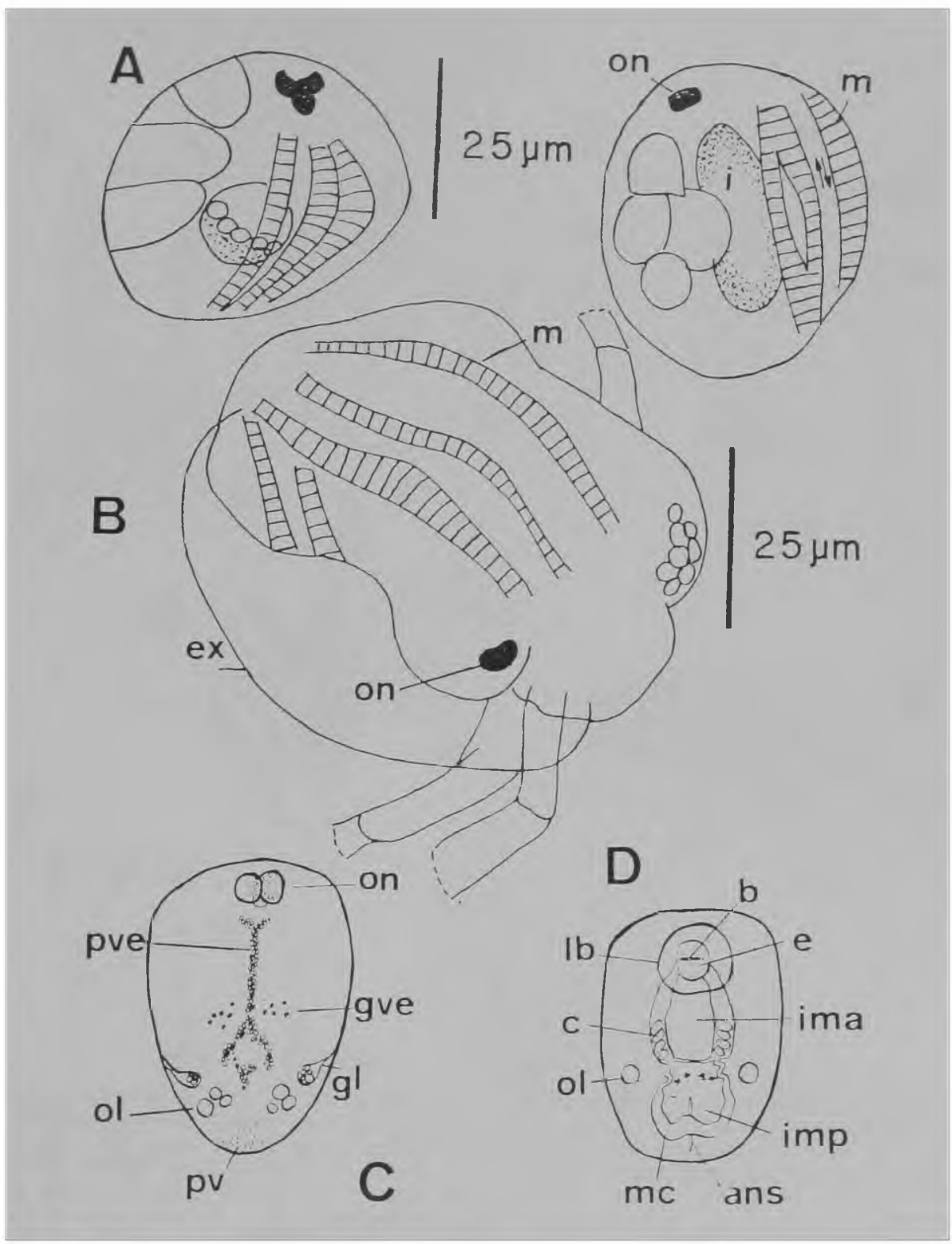

Fig. 2 - A - Egg of Oithona ovalis, near to hatching, with internal structures visible. The arrows indicate muscle movement. B - O. ovalis leaving the egg envelope, during a resting period, before the final movements to get rid from the egg envelope. C - Scheme showing the distribution of oil droplets and pigments in dorsal view. $\mathrm{D}-$ The digestive system seen in ventral view, with arrows indicating its contractions. Symbols: ans = anus; $\mathrm{b}=$ mouth; $\mathrm{c}=$ urine concretion sac; e = oesophagus; ex = egg envelope; gl = gland; gve = red fat deposit; ima = anterior midgut; imp = posterior midgut; $\mathrm{lb}=$ labrum; $\mathrm{m}=$ striated muscles; $\mathrm{mc}=$ circular muscles; ol = green or ochre oil deposit; on = naupliar eye; $\mathrm{pv}=$ yellow pigment of the cuticle; pve $=$ dark green pigment. 
Fig. 3 - Nauplius II of Oithona ovalis: A - Detail of the transition region from the anterior midgut to the posterior with arrows indicating direction of movements; B - Schematic representation of the muscle distribution in dorsal view; C - Detail of the anterior region in dorsal view; $D$ - Detail of the labrum in ventral view; $\mathrm{E}$ - Lateral view; the muscles of each appendage; $\mathrm{F}$ - Dorsal schematic view of the distribution of the pigments and of the fat droplets; $G$ - Lateral view of the digestive tract; $\mathrm{H}$ - The digestive tract from a ventral plane; I — Detail of the posterior region of the nauplius focalized from a median plane. Symbols used: $\mathrm{al}=$ antennule; $\mathrm{an}=$ antenna; ant. = anterior direction; $\mathrm{b}=$ mouth; $\mathrm{c}=$ urine concretions; $\mathrm{e}=$ oesophagus; es $=$ empty space (transitory crystalline); $\mathrm{gl}=$ gland; gve = red fat deposit; ima = anterior midgut; imp = posterior midgut; ip = hindgut; $\mathrm{lb}=$ labrum; $\mathrm{m}=$ striated muscles; mal = antennule muscles; $\mathrm{mc}=$ circular muscles; $\mathrm{mn}=$ mandible; ngf $=$ nerve lying in the direction of the $\mathrm{X}$ organ; ol = green or ochre oil deposit; on = naupliar eye; ot $=$ oil deposit in a special tissue; no $=$ optic nerve; $\mathrm{p}=$ dark dorsally situated pigment; $\mathrm{pa}=$ yellow pigment of the cuticle; pve $=$ dark green pigment; $q=$ cuticular thickenning; $\mathrm{ra}=$ rests of digested food mass; $\mathrm{sn}=$ brain . 
A

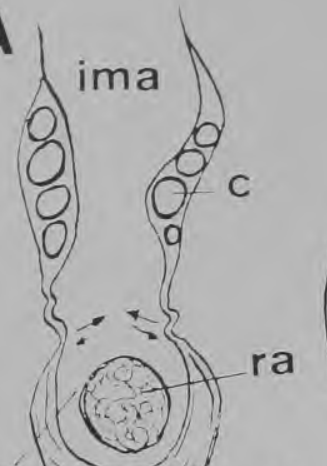

$\operatorname{imp}=\mathrm{mc}$

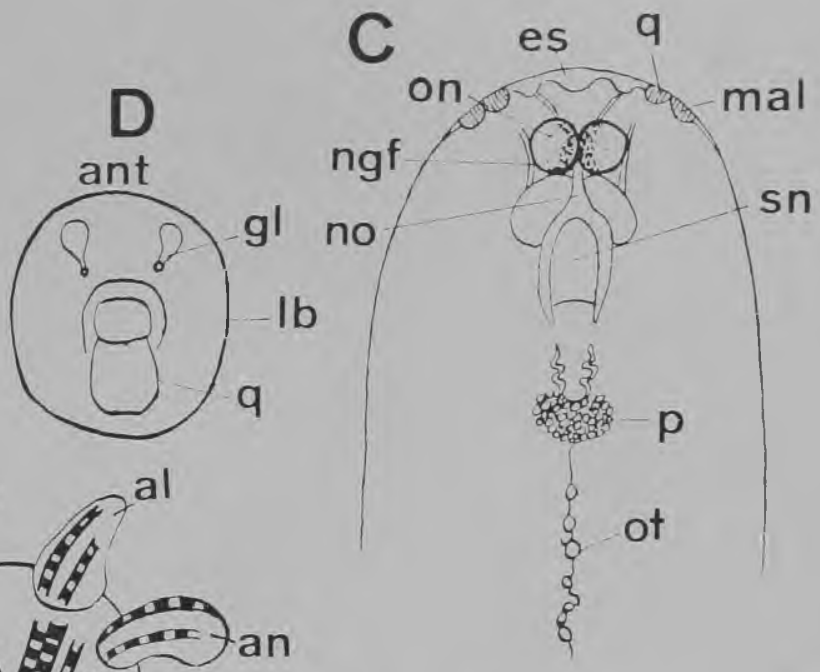

F
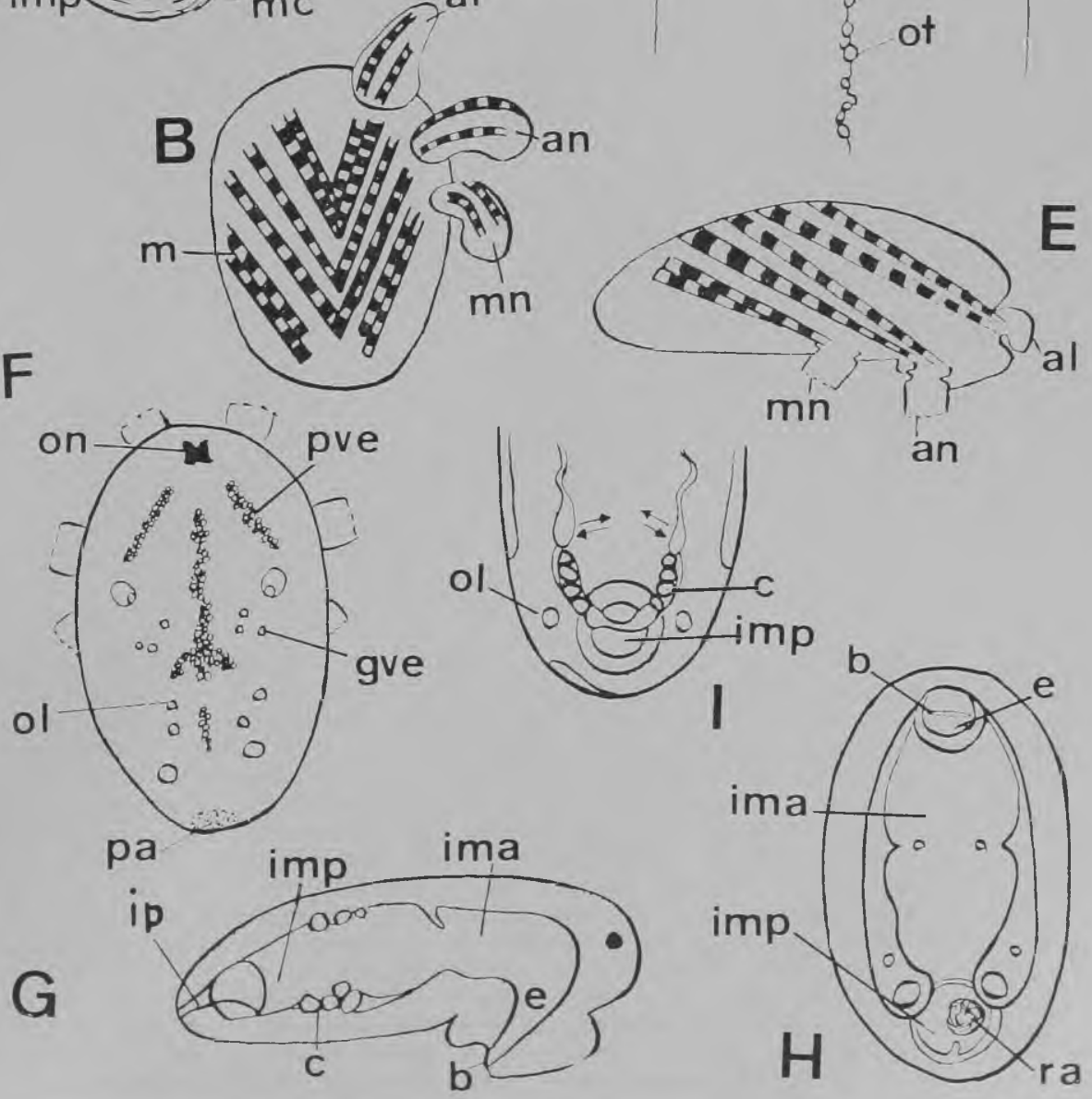

$\mathrm{mn}$ 
Fig. 4 - Nauplii III and IV of Oithona ovalis: A - Neuplius III: dorsal schematic view of the distribution of pigment and oil droplets; B - Detail of the dorsal view of the same; $\mathrm{C}$ - Frontal view, showing the relationship between the naupliar eye and the thickenning of the cuticle in nauplius III; D - Latero-dorsal view of the distribution of the muscles in nauplius III; E - Detail of the posterior region in ventral view of nauplius III; F - The digestive system of nauplius III in ventral view (the arrows indicate the direction of the movements); $G$ - Nauplius III seen in a more median plane - detail of the concretion sac; J - The labrum of nauplius IV; $\mathrm{H}$ - Detail of the anterior region of nauplius IV in dorsal view; I - The schematic distribution of pigment, oil droplets and segments in nauplius IV. Symbols used: $\mathrm{al}=$ antennule; an = antenna; $\mathrm{b}=$ mouth; $\mathrm{c}=$ urine concretions; $\mathrm{cl}=$ cells; $\mathrm{cp}=$ transitory crystalline; $\mathrm{e}=$ oesophagus; $\mathrm{eq}=$ cuticle thickennig; $\mathrm{fm}=$ median fissure of brain $; \mathrm{gl}=$ gland; $\mathrm{ima}=$ anterior midgut; $\mathrm{imp}=$ posterior midgut; $\mathrm{lb}=$ labrum; $\mathrm{l} c=$ corneal lens; $\mathrm{lm}=$ median line; $\mathrm{mc}=$ circular muscles; $\mathrm{mn}=$ mandible; nof = organ X nerve; ol = green, ochre or red oil droplet; olv = oil droplets of various colors; on = naupliar eye; $\mathrm{p}=$ dark pigment; $\mathrm{pa}=$ yellow cuticular pigment; pgl $=$ gland pore; $q \mathrm{pm}=$ chitin seen in a median plane; $\mathrm{sf}=$ sphincter; $\mathrm{sn}=$ brain; $\mathrm{sv}=$ segment focalized in a ventral plane; $\mathrm{tm}=$ muscles; ts = supporting tissue. 
A
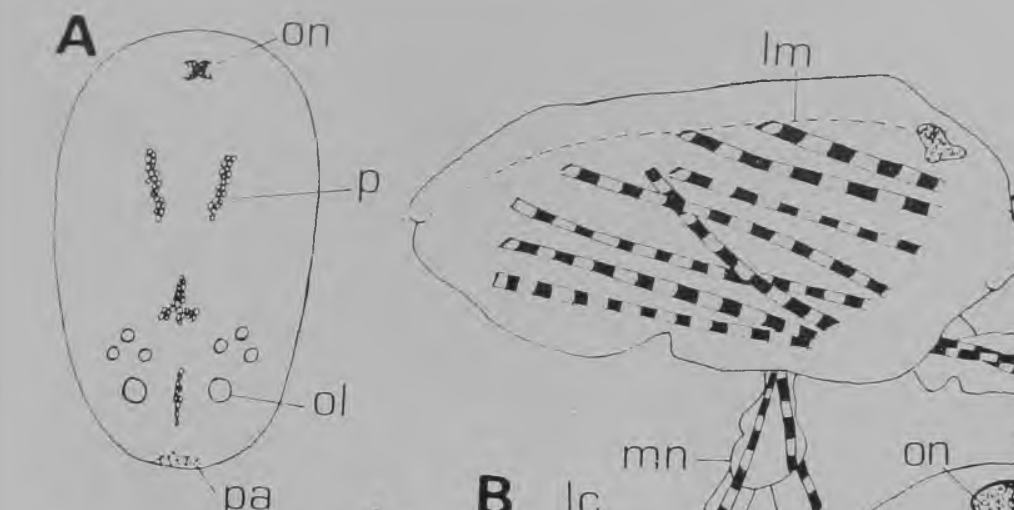

D

F

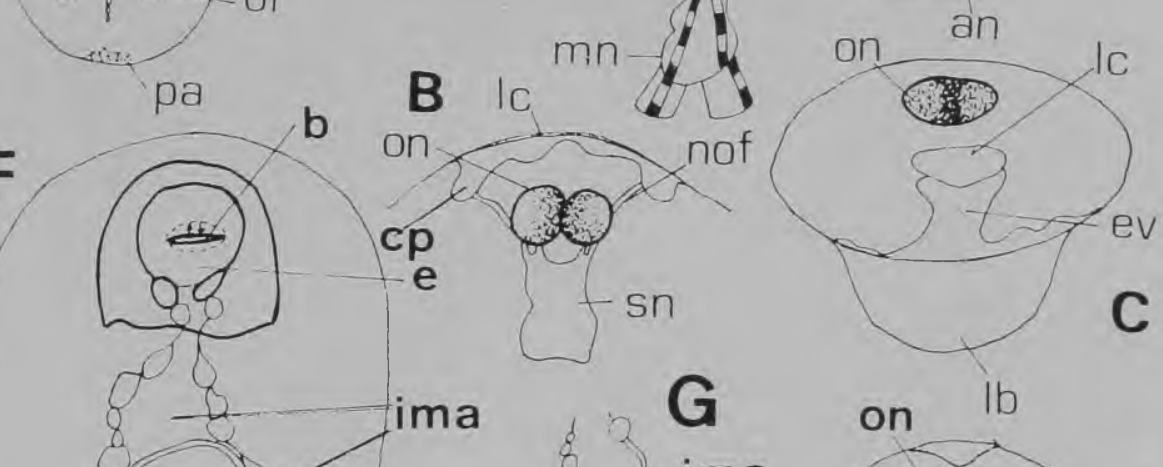

$m n$

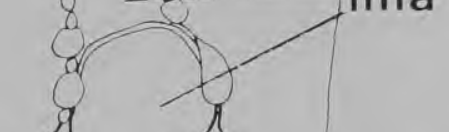

(8)

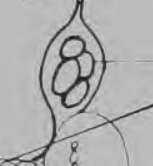

- 8060

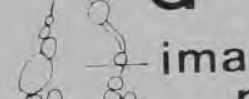

\&8 \&o ima pv
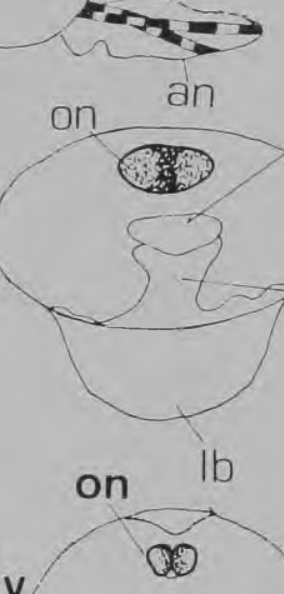
Fig. 5 - Nauplius IV and $v$ of Oithona ovalis: A - dorsal schematic view of musculature of nauplius IV; B - The digestive system of nauplius IV in ventral view; $C$ - Schematic representation of the dorsal view of nauplius $V$ with the distribution of pigments and oil deposits; $\mathrm{D}$ - Labrum of nauplius $\mathrm{V}$ in ventral view; E - Dorsal view of the muscles occurring near the surface and the surface oil deposits of nauplius $\mathrm{V} ; \mathrm{F}-$ The digestive system of nauplius $\mathrm{V}$ in ventral view; $\mathrm{G}$ - The same focalized in a more median plane. Symbols used: al = antennule; an $=$ antenna $;$ ans $=$ anus $; \mathrm{b}=$ mouth $; \mathrm{c}=$ urine concretions $; \mathrm{cl}=$ cells $; \mathrm{cv}=$ green cells; $\mathrm{e}=$ oesophagus; $\mathrm{di}=$ intestine division; $\mathrm{gl}=$ gland; ima $=$ anterior midgut; $\mathrm{imp}=$ posterior midgut; $\mathrm{lb}=$ labrum; mal $=$ antennule muscles; man = antenna muscles; $\mathrm{mc}=$ circular musculature; $\mathrm{mmn}=$ mandible muscles; $\mathrm{mmx}=$ maxillule muscles; $\mathrm{mn}=$ mandible; $\mathrm{mx}=$ maxillule; ol = green or ochre oil deposits; $\mathrm{ov}=$ red oil deposit; $\mathrm{pa}=$ yellow cuticular pigment; pve $=$ dark pigment; $\mathrm{q}=$ chitin thickenning; $\mathrm{s}=$ segment; $\mathrm{sf}=$ sphincter; $\mathrm{tm}=$ muscle fibres. 


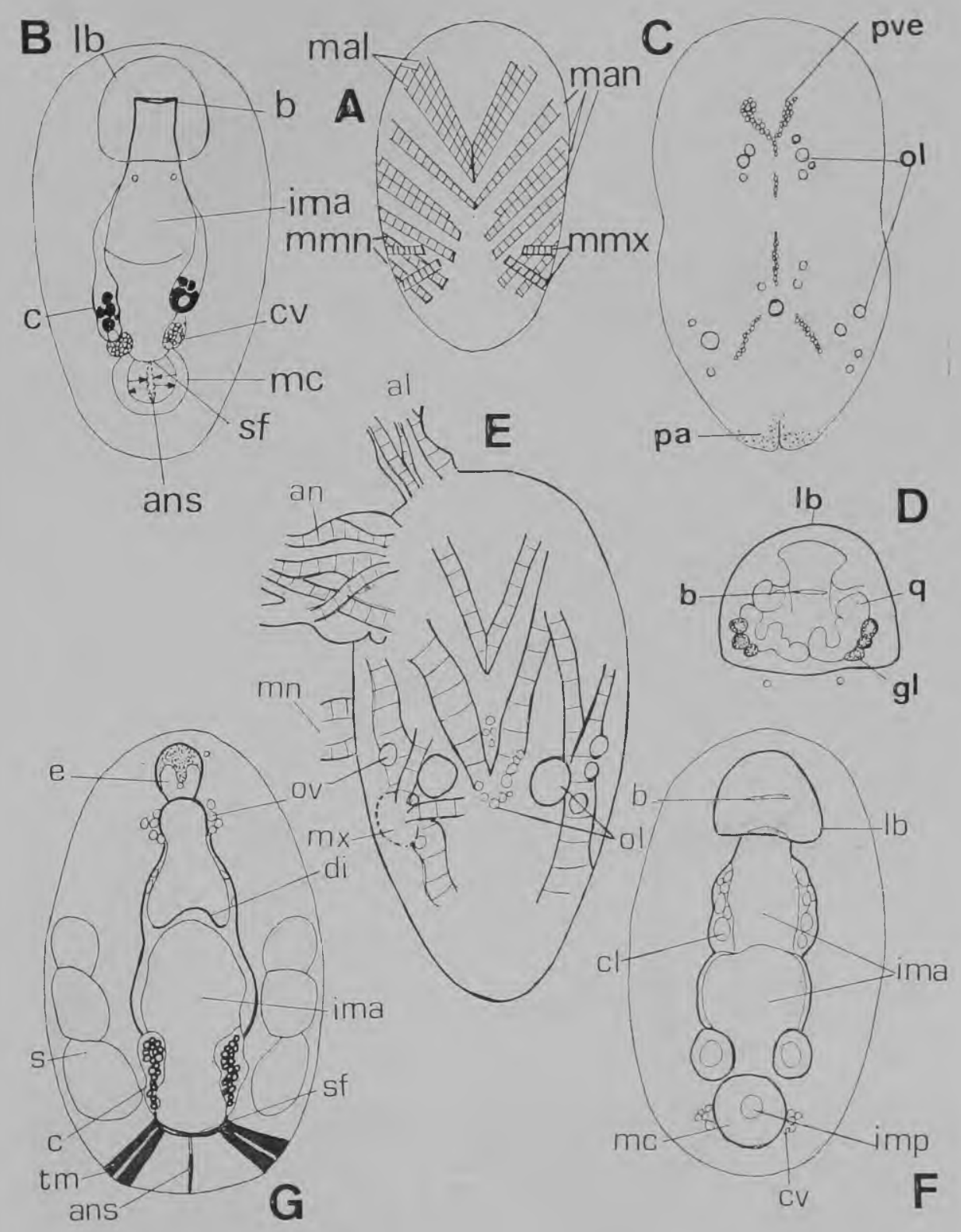


Fig. 6 - Nauplius VI of Oithona ovalis: A - Schematic distribution of the oil deposits, glands and pigments in dorsal view; B - Scheme of the posterior region in lateral view; C - Digestive tract focalized in a dorsal plane; D - The same focalized in a ventral plane. Symbols: ans $=$ anus; $\mathrm{b}=$ mouth; $\mathrm{c}=$ urine concretions; $\mathrm{di}=$ intestinal division; $\mathrm{e}=$ oesophagus; $\mathrm{egl}=$ glandular epithelium; gl = gland; glv = green gland; ima = anterior midgut; imp = posterior midgut; $\mathrm{lb}=$ labrum; $\mathrm{mc}=$ circular musculature $;$ ol $=$ green or yellow oil deposit; ot $=$ oil deposit in tissue; ov $=$ red oil deposit; $p=$ cuticle pigmentation; pa = yellow pigment of cuticle; pe $=$ dark pigment; $q=$ tuticle thickennig; $s=$ segments; sf $=$ sphincter. 

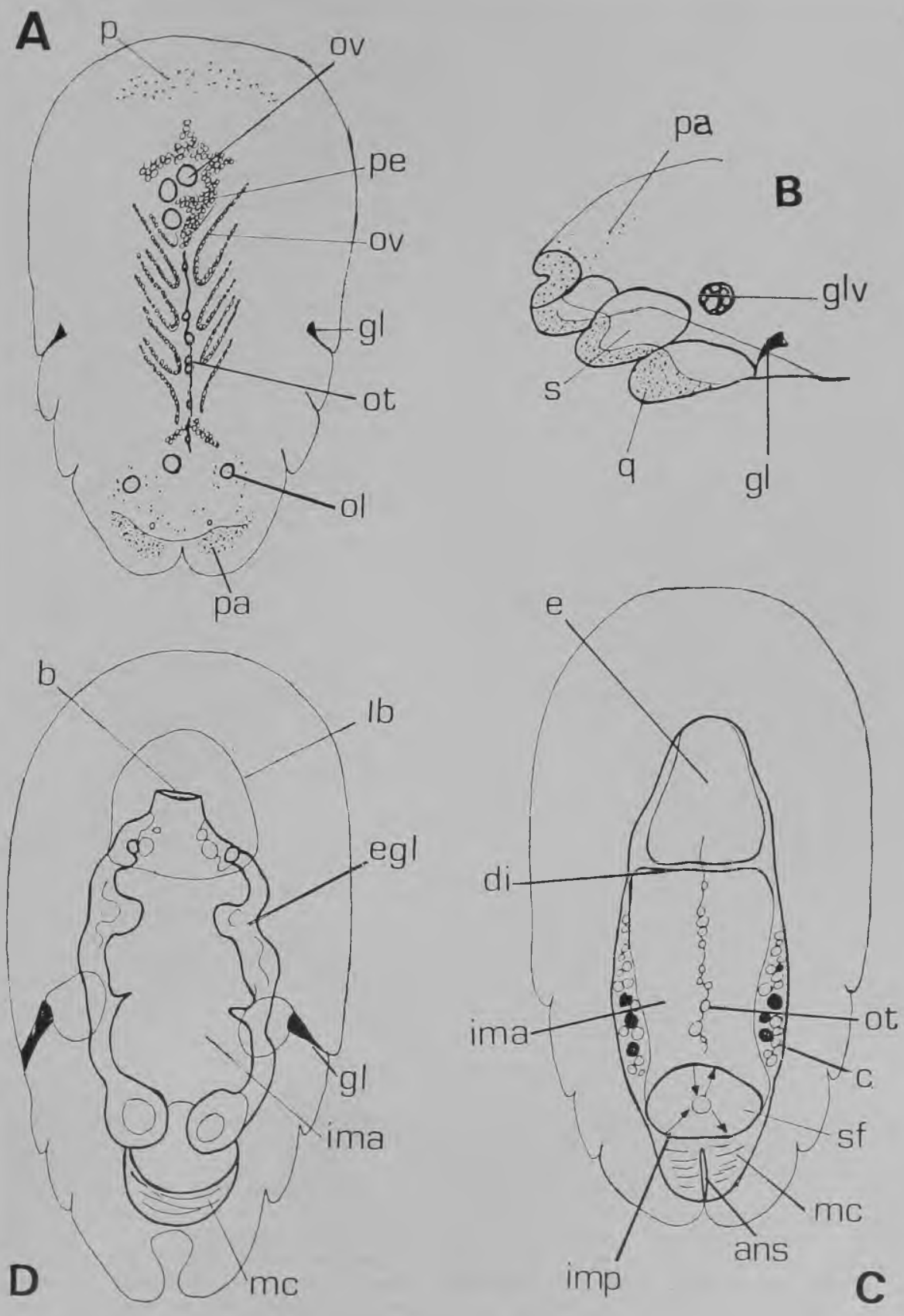
Fig. 7 - Nauplius VI of Oithona ovalis: A - General scheme of the distribution of the chitin thickennings and the segments in a ventral plane; B - Detail of the segments focalized in a more median plane; $\mathrm{C}$ - Lateral view of the appendage muscles; D - Detail of the anterior region in a dorsal view with the relationship between the nervous system and the brain; E - Dorsal view of the surface-lying muscles and fat deposits. Symbols: $\mathrm{cp}=$ transitory crystalline; $\mathrm{f}=$ median fissure of brain; $\mathrm{lc}=$ corneal lens; $\mathrm{m}=$ striated muscles; $\mathrm{mal}=$ antennular muscles; man = antennal muscles; $\mathrm{mmn}=$ mandible muscles; $\mathrm{mmx}=$ maxillular muscles; nof $=$ organ $\mathrm{X}$ nerve; ol $=$ yellow or green oil deposit; on = naupliar eye; ov $=$ red oil deposit; $q=$ thickenning of the cuticle; $s=$ internal segmentation; sn $=$ brain; ts $=$ supporting tissue. 


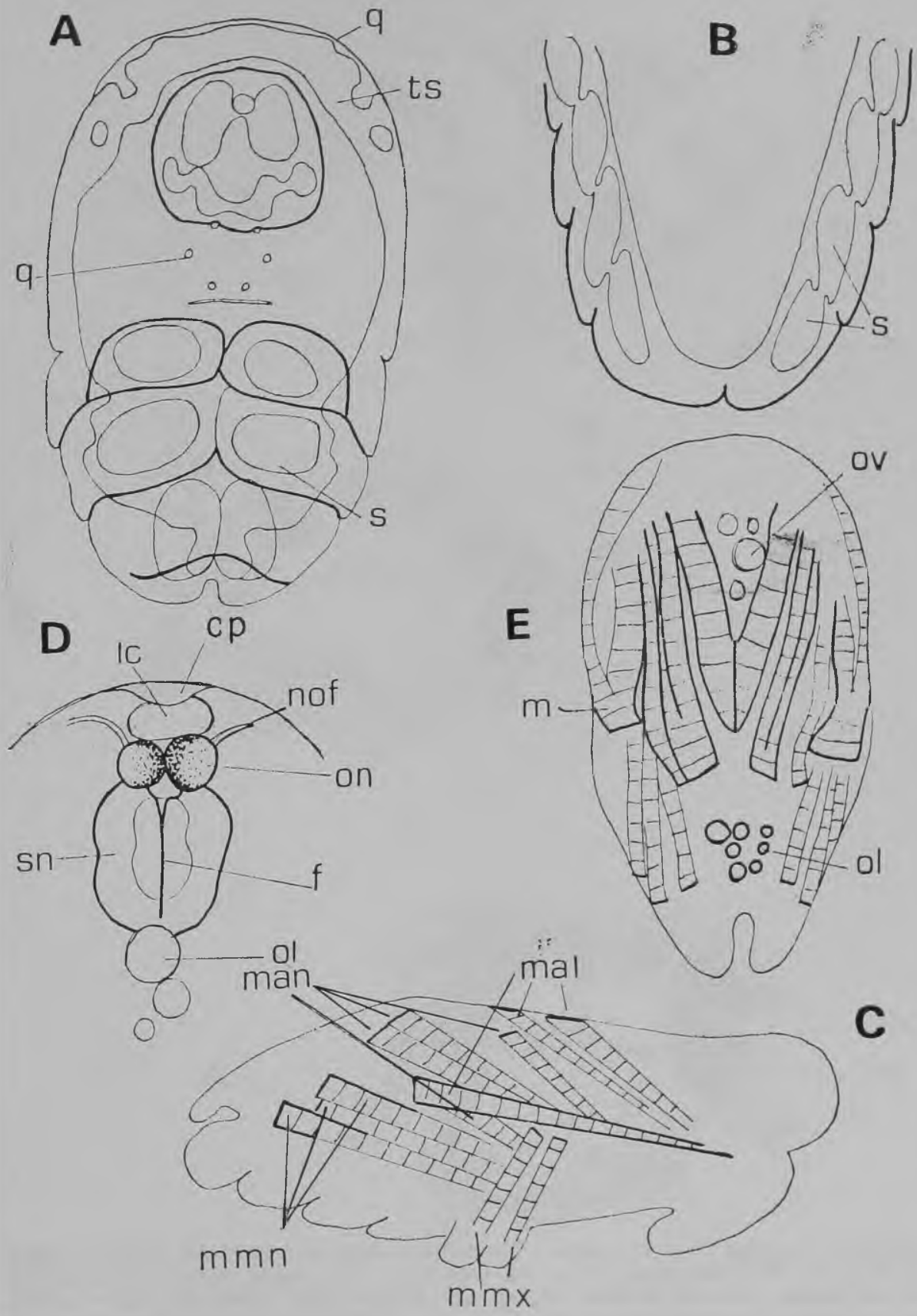


Fig. 8 - Nauplius III of $O$. ovalis. Transverse serial sections in the anterior region of the body from the front (A) to the back (C). The upper region of the section is the dorsal, and the inferior region, the ventral side. Symbols: $g$ = gland; gn $=$ nervous ganglium; $\mathrm{i}=$ terminal region of the oesophagus; $\mathrm{m}=$ appendage muscles; $\mathrm{mc}=$ circular musculature; $\mathrm{s}=$ mucous secretion; $\mathrm{sn}=$ nervous sustem; ts = supporting tissue. 


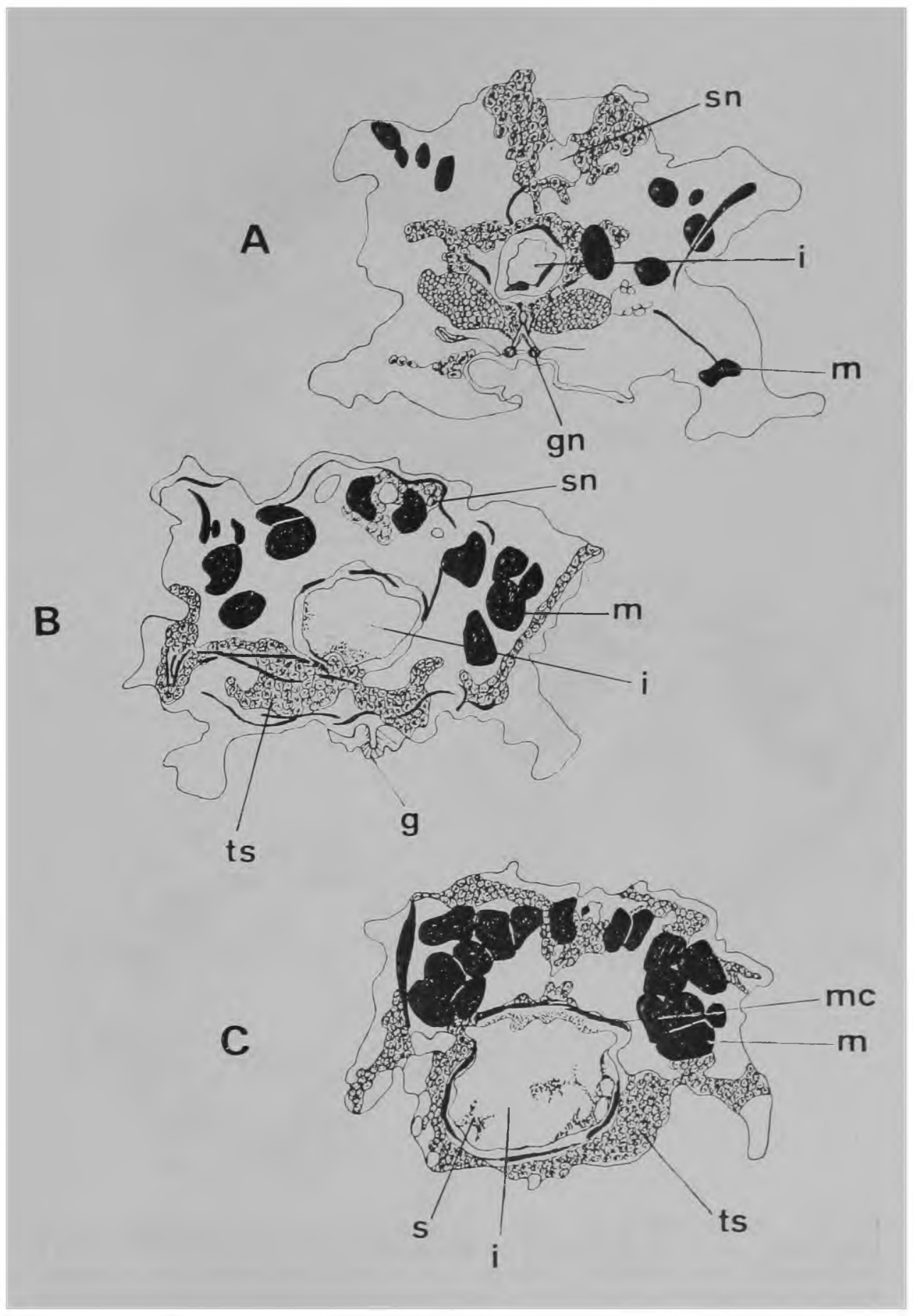


Fig. 9 - Nauplius III of $O$. ovalis: Serial sections of Fig. 8 continued, section being more posterior than section $\mathrm{C}$ of the preceding Figure, and sections $\mathrm{B}$ and $\mathrm{C}$ progressively more posterior. Symbols: $\mathrm{c}=$ urinary concretions; ima $=$ anterior midgut; $\mathrm{m}=$ appendage musculature; $\mathrm{mc}=$ circular muscles; $\mathrm{s}=$ mucous secretion; $\mathrm{sn}=$ nervous sstem; ts = supporting tissue. 


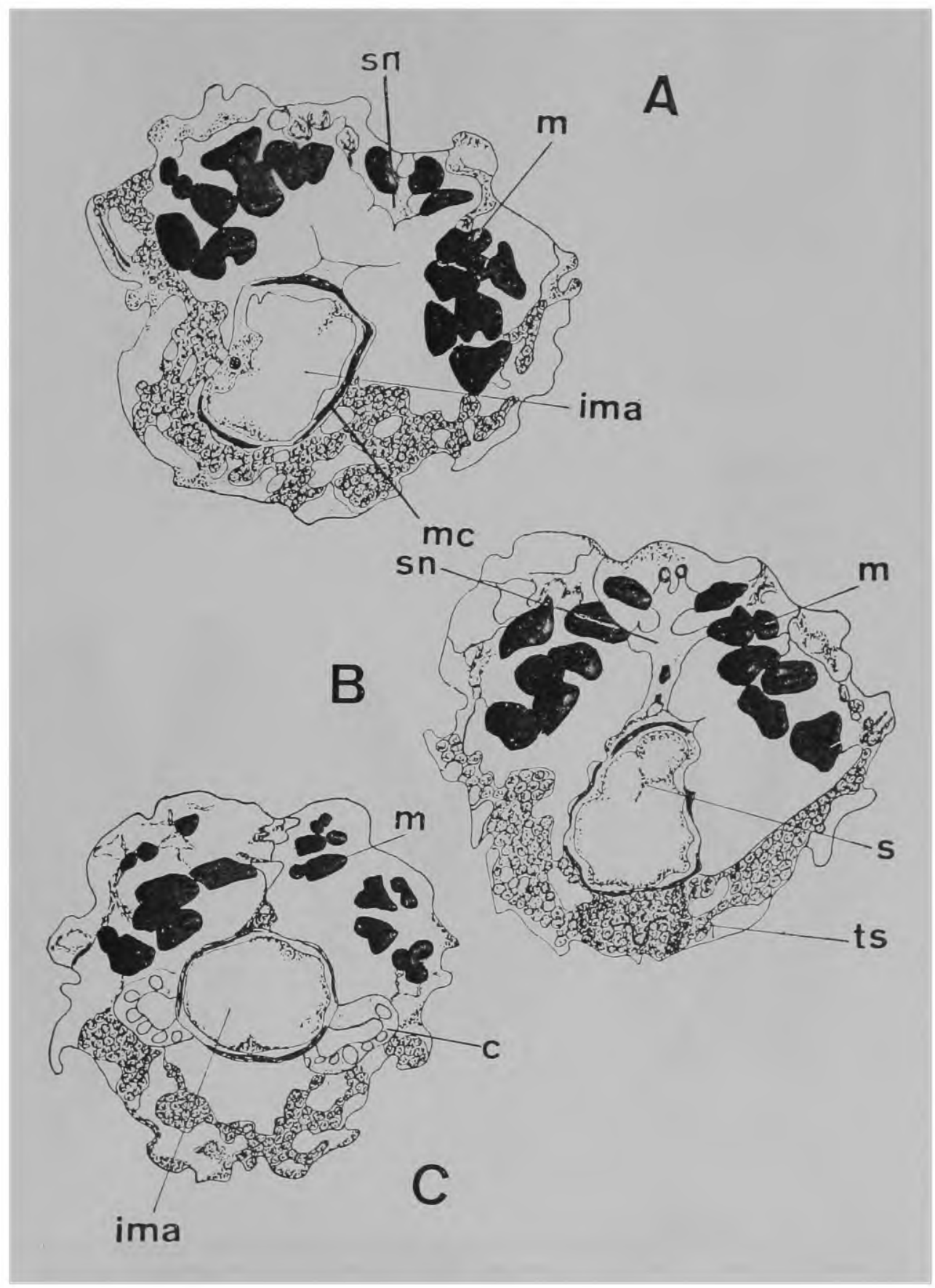


Fig. 10 - Schematic representation of the appendage muscles in the 6 naupliar stages of Oithona ovalis. Symbols: al = antennular muscles; an $=$ antennal muscles; $\mathrm{mn}=$ mandible muscles; $\mathrm{mx}=$ maxillule muscles; $\mathrm{N}_{1}-\mathrm{N}_{6}-$ the naupliar stages from I to VI. 

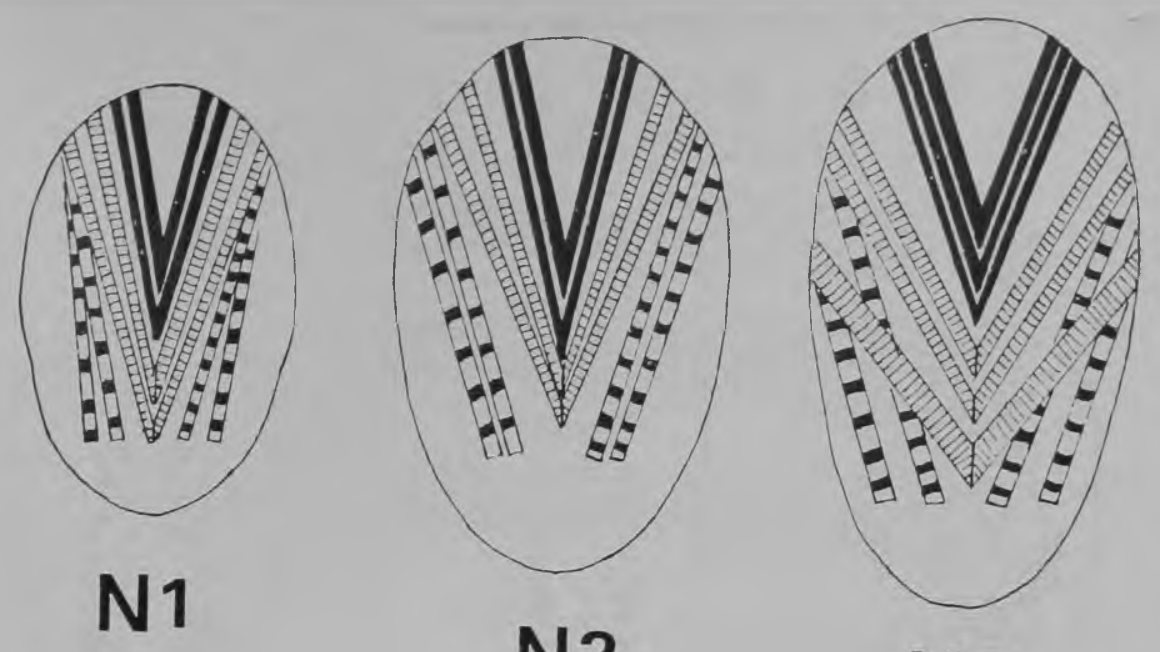

N2

N3
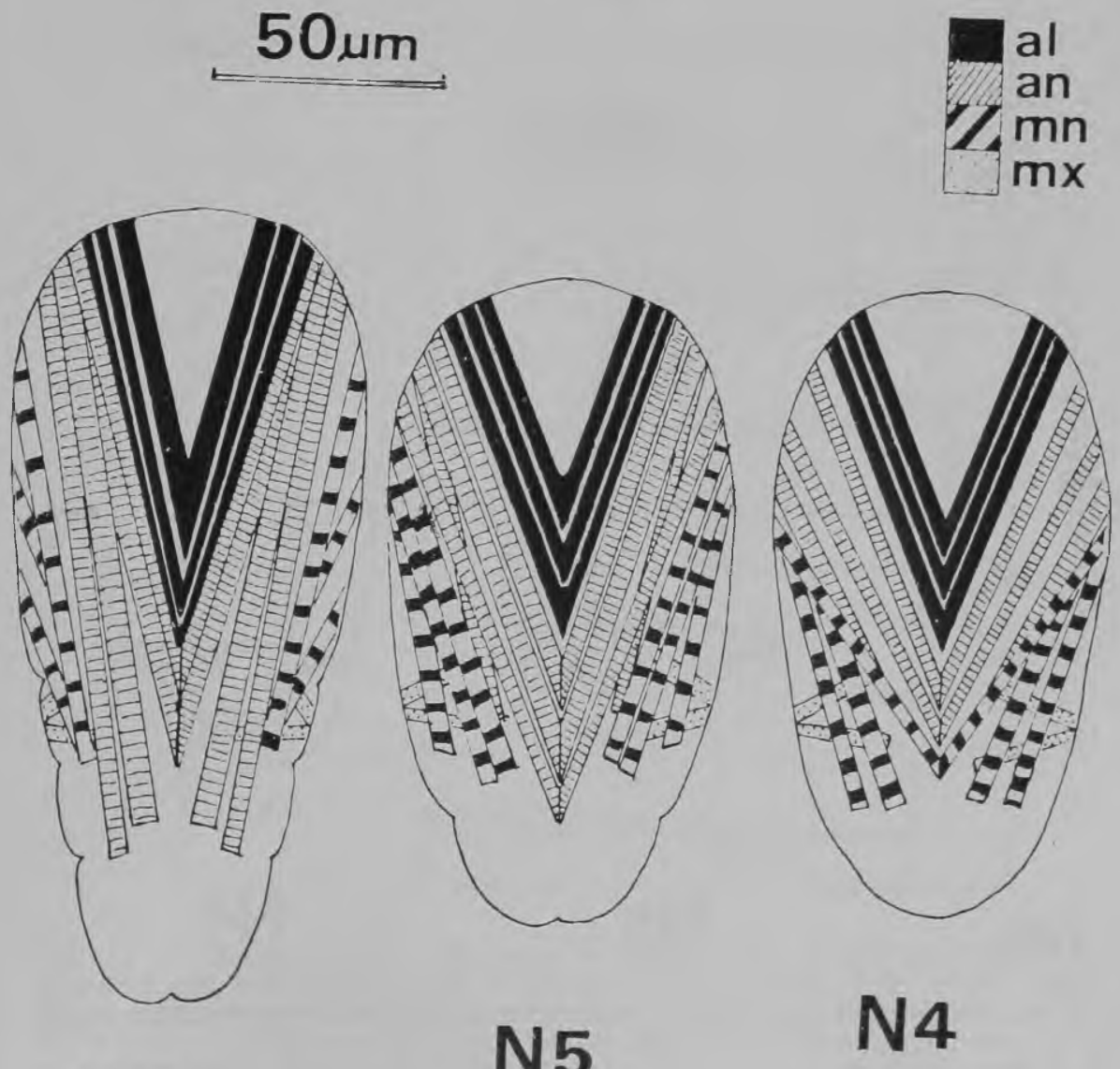

N6

N5 


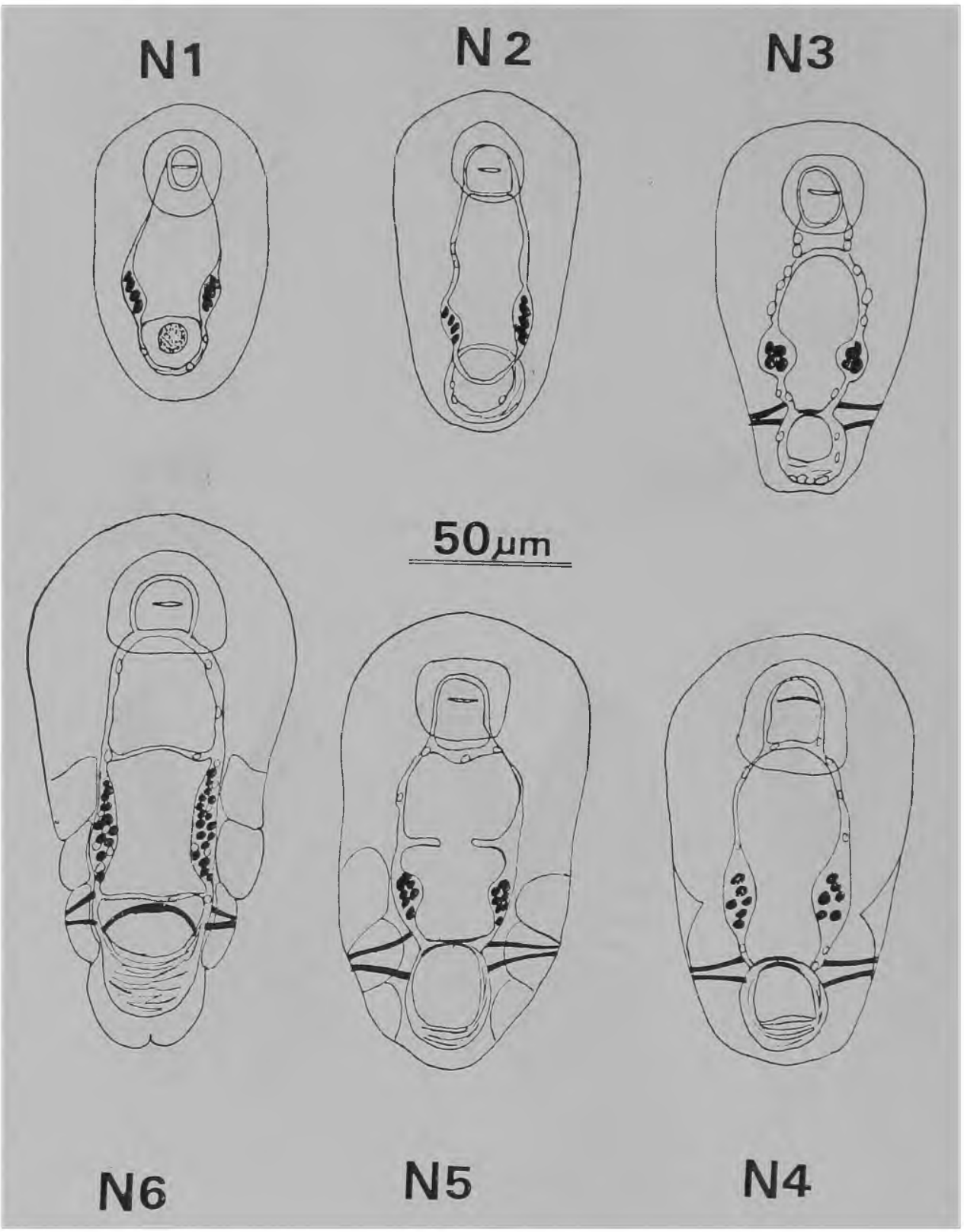

Fig. 11 - The digestive system of $O$. ovalis schemathized in the six naupliar stages $\left(N_{1}\right.$ to $\left.N_{6}\right)$. 


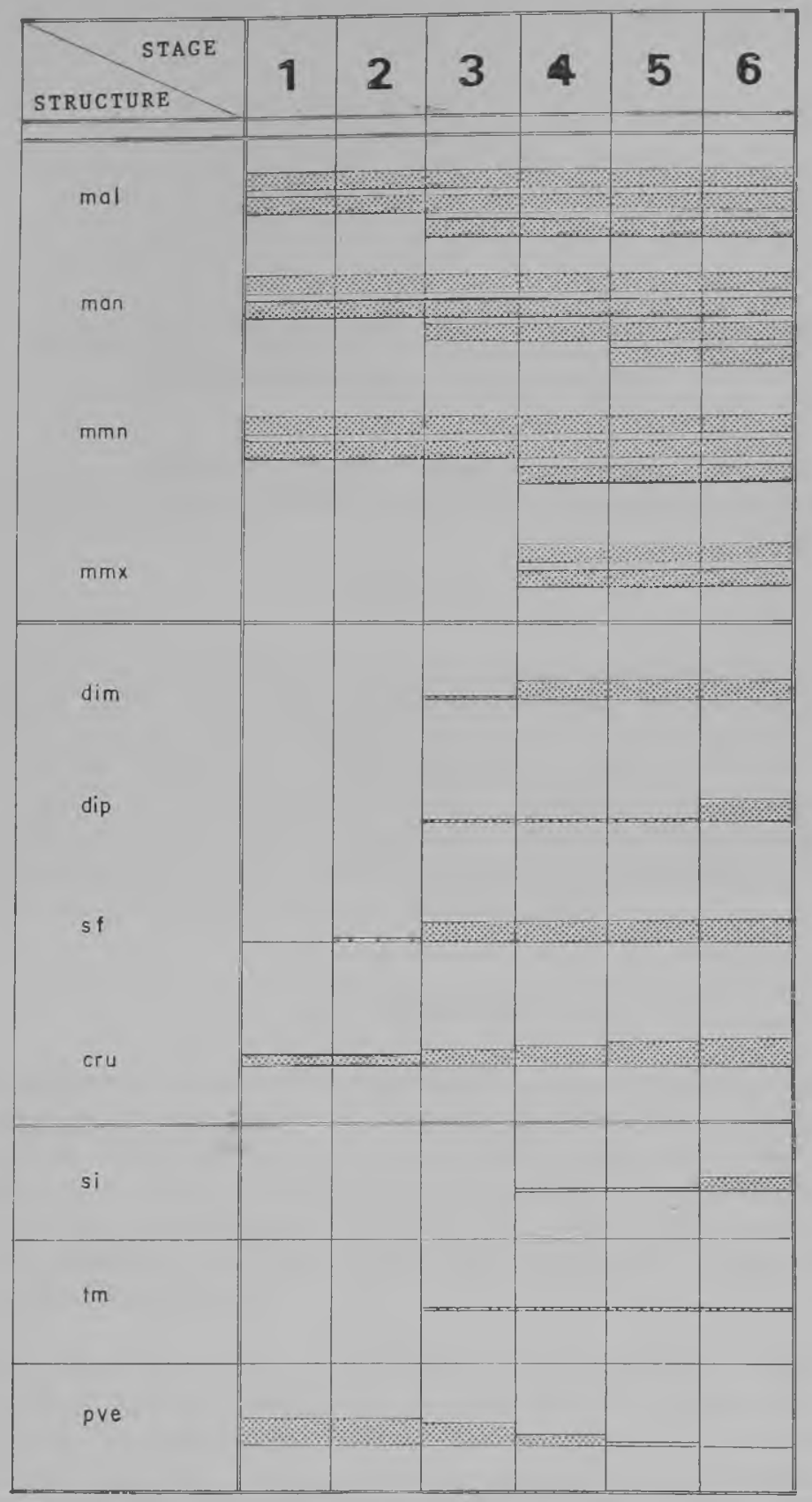

Fig. 12 - Graph showing the stage in which some of the naupliar structures appeared and their development in the 6 naupliar stages of O. ovalis. Symbols: cru = urine concretions; $\operatorname{dim}=$ anterior division of the anterior midgut; dip = posterior division of the anterior midgut; $\mathrm{mal}=$ antennular muscle pairs; man $=$ antennal muscle pairs; $\mathrm{mmn}=$ mandibular muscle pairs; $\mathrm{mmx}=$ maxillular muscle pairs; pve $=$ bar of dark pigment; $s f=$ sphincter; $s i=$ internal segmentation; $\mathrm{tm}=$ muscles from the body wall to the digestive tract. 
